\title{
Comparison of Internal and External Prestressing for Typical Highway Bridges
}

\author{
Olivier BURDET \\ Lecturer \\ EPFL \\ Lausanne, Switzerland \\ Olivier Burdet, born 1960, is a \\ lecturer in reinforced and \\ prestressed concrete. His \\ research interests include \\ serviceability, bridge design \\ and monitoring techniques. \\ $\mathrm{He}$ is a member of WC 3 and \\ of the Publication's Committee \\ of IABSE's SEI Journal.
}

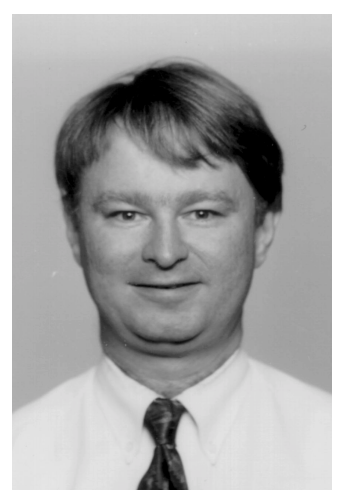

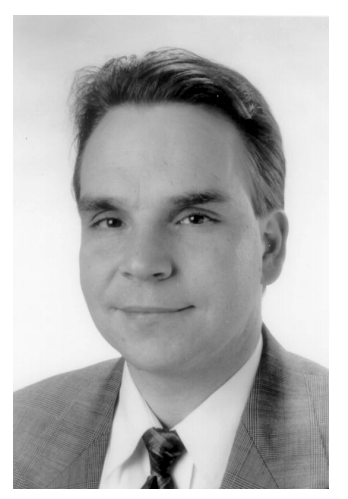

\section{Summary}

The paper presents an analytical comparison of the amount of prestressing required for two similar bridges, one with internal and the other with external prestressing. This comparison shows that bridges with external prestressing can become economically competitive for large girder depths. The detrimental effect of the smaller stress in the prestressing steel at the ultimate limit state is more than compensated by the thinner webs made possible by the absence of ducts.

Keywords: prestressed concrete, external post-tensioning, amount of prestressing, serviceability design, ultimate limit state design

\section{Introduction}

External prestressing offers designers the potential to create structures that have a better durability, and that can easily be retrofitted in the case of deterioration, or to increase their capacity. This is a very important characteristic for urban bridges, for which traffic interruptions pose a real problem. Durability problems with existing bridges with internal, non-replaceable prestressing, have led to an increased interest for external prestressing, to the point that it is now the preferred technology in Germany for box girder bridges [15]. External prestressing also holds interesting promises in that it gives more freedom to the designer in the choice of the shape of the cross section. This freedom is essential for an optimal use of very high strength materials.

It is generally thought that a change from internal to external prestressing results in a significant increase in the amount of reinforcement required. Regardless of the respective technological advantages of the two solutions, this paper attempts to provide insight on the quantitative differences that results from the choice of a solution with internal or external prestressing. A comparative study was performed on two realistic models of a five spans continuous single-cell box girder : one with internal and the other with external prestressing. The parameters investigated are the bridge span and the depth of the girder. Only a preliminary design was performed, to determine the amount of prestressing, of flexural reinforcement, and of shear reinforcement. The design was carried in accordance with the current Swiss design codes $[13,14]$, but most of the results have a general validity.

The paper highlights the most significant parameters and shows that, in a large number of cases, the use of external post-tensioning does not significantly increase the cost of the structure.

\section{Highway bridge models}

An extensive parametric study was performed on a realistic model of a typical highway bridge. The structure is continuous box girder bridge with a constant depth. To minimize the effect of side spans, which have a large influence on the design of the prestressing, the structure has five spans (fig. 1). The tendons are laid out in a classic parabolic shape for the internal prestressing (fig. 1a) and in a trapezoidal layout with two deviators in the span for the external prestressing (fig. 1b). The 
cross section (fig. 2) has a constant depth, with a thicker bottom flange on intermediate supports. The webs of the bridge with external prestressing are thinner $(0.3 \mathrm{~m})$ than the webs of the bridge with external prestressing $(0.5 \mathrm{~m})$ to account for the easier concreting conditions without web tendons. The bottom flange is $0.2 \mathrm{~m}$ thick in the span and $0.4 \mathrm{~m}$ over intermediate supports.

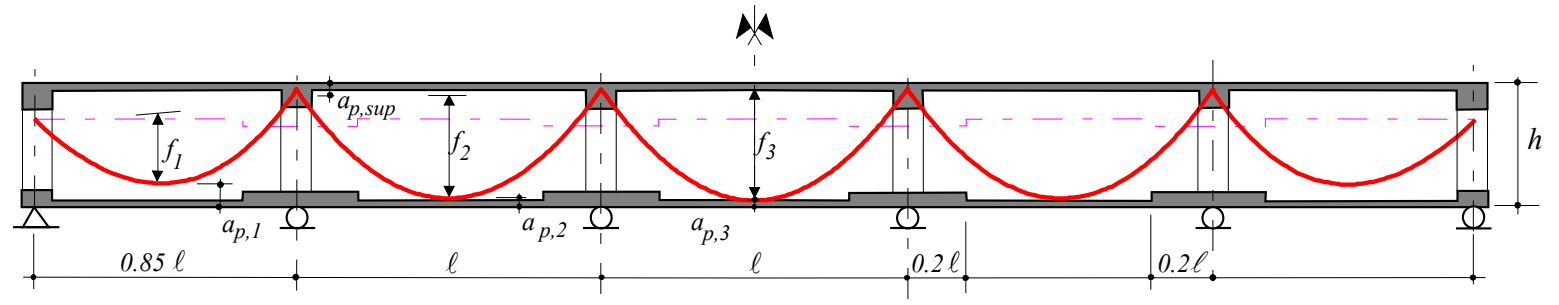

a) Geometry with internal prestressing

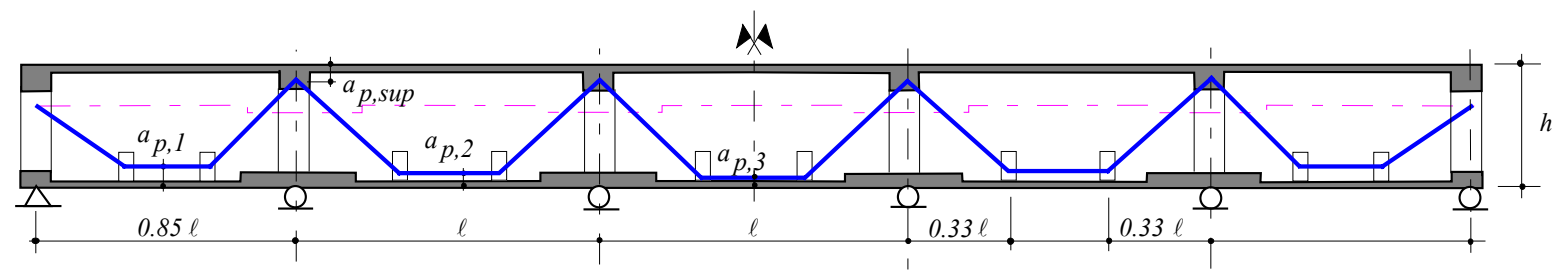

b) Geometry with external prestressing

Figure 1: $\quad$ Elevation of the model bridges
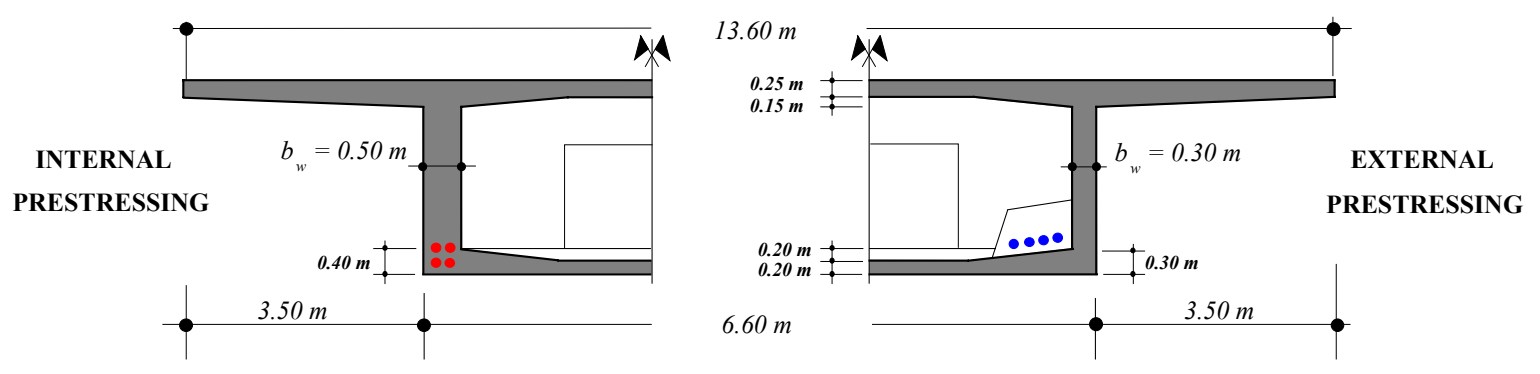

Figure 2: $\quad$ Cross section of the model bridges

The prestressing was determined on the basis of serviceability criteria to reach a level of compensation of deflections of $\beta=0.8[10,11]$. This level is represents the amount used in many structures and typically ensures a satisfactory behavior in service. It has the further advantage of being totally independent from codes.

The tendon layout was fine tuned to ensure that the level of compensation of deflections $\beta$ be identical in all spans. This was achieved by setting the length of the side spans to $85 \%$ of the main spans, and by fine tuning the position of the cable at its lowest point ( $a_{p, n}$ in fig. 1).

The tendon layout for the external prestressing is trapezoidal with two deviators in the span. While the location $\lambda$ of the deviators in the span can be chosen by the designer, figure 3 shows that it influences the amount of prestressing required to achieve a desired level of compensation of deformations $\beta$. The optimal location for these deviators is at $3 / 8$ and $5 / 8$ of the span. This value can be analytically derived for simple configurations. In the present study, the span deviators are located at $1 / 3$ of the span, which is close to the optimum. The amount of prestressing required to achieve the same level of compensation of deflection with a parabolic cable would be larger. 


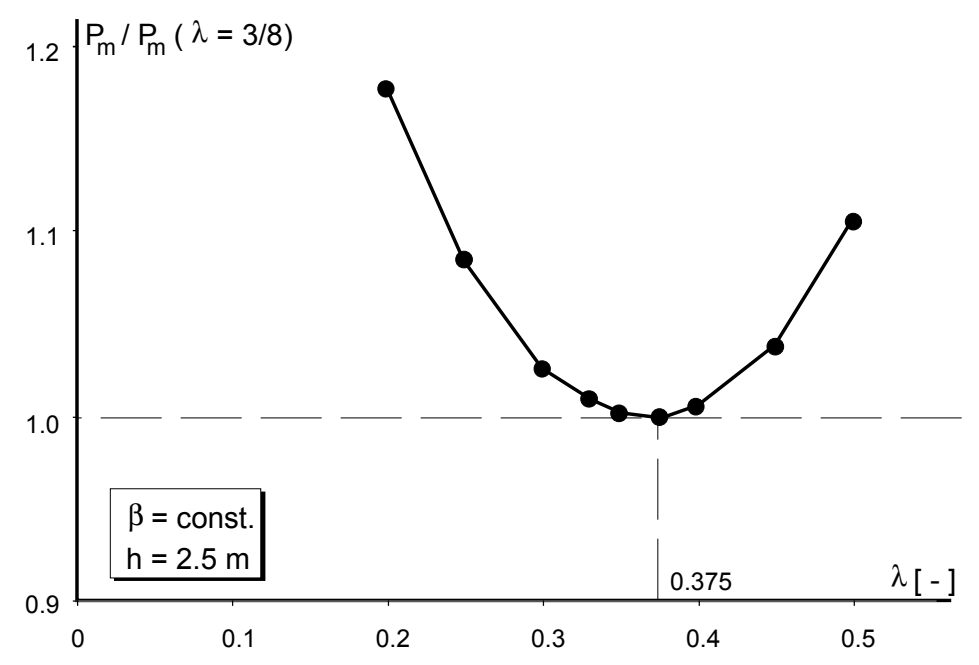

Figure 3: $\quad$ Influence of the span deviator position on the required amount of prestressing

\section{Parametric study}

The comparative parametric study was performed using a simple analytical model of each structure implemented in a spreadsheet program. The two main parameters of the investigation are :

- $\operatorname{girder} \operatorname{span}(30$ to $80 \mathrm{~m})$

- girder depth (girder span-to-depth ratios 15 to 25 )

The results presented hereafter are valid within the limits, and for the assumptions of this parametric study, which covers multiple span continuous bridges with a constant depth. The range of spans and girder depths considered includes the majority of structures in that category that may be considered for an application of external prestressing. Bridges with very small girder depths (less than $1.8 \mathrm{~m}$ ) are typically considered impractical for such applications.

Figure 4 shows the required amount of prestressing force as a function of the main bridge span for bridges with internal and external prestressing. As expected, the amount of prestressing increases with increasing spans and span-to-depth ratio. At low values of the span, solutions with internal prestressing require a larger amount of prestressing, mainly because the available cable sag is significantly smaller than for internal prestressing (fig. 2). For larger spans, however, this influence diminishes, and is more than compensated by the reduction in weight caused by the thinner webs. Thus, solutions with external cables require typically less prestressing for a given level of compensation of deflections $\beta$ for spans exceeding 40 to $60 \mathrm{~m}$ (location of the stars in fig. 4).

Figure 5 shows the same data in a different format: the required amount of prestressing is clearly shown to be lower for the solution with internal prestressing for girder depths smaller than $3 \mathrm{~m}$, and larger above that value. In most cases, these differences are small, and it can be concluded that, from a serviceability point of view, the two prestressing types are very close to one another.

Finally, it must be noted that part of this advantage is due to the more efficient cable layout used for external prestressing. It has been shown above that a trapezoidal cable layout used is more efficient than the usually adopted parabolic layout (fig. 3). Since this layout is very common, it has been nevertheless used for internal tendons in this study. 


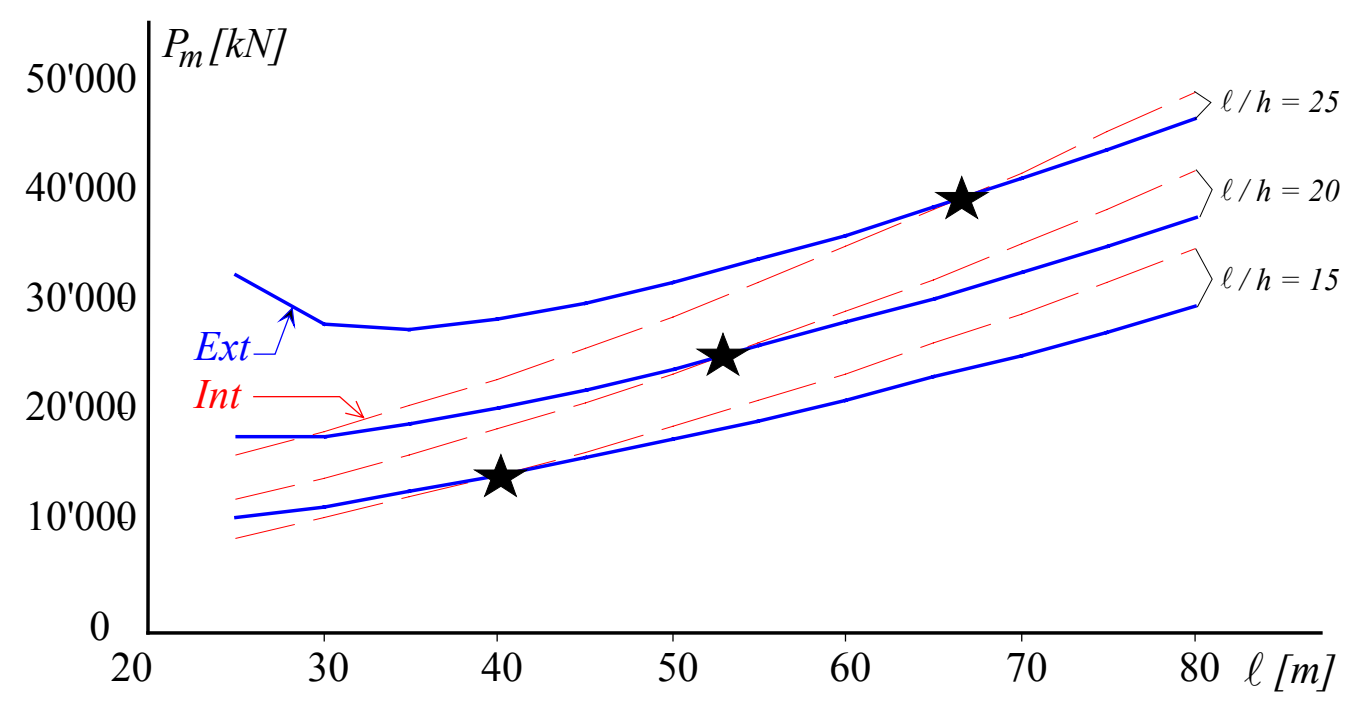

Figure 4: $\quad$ Required prestressing force for internal and external prestressing for $\beta=0.8$

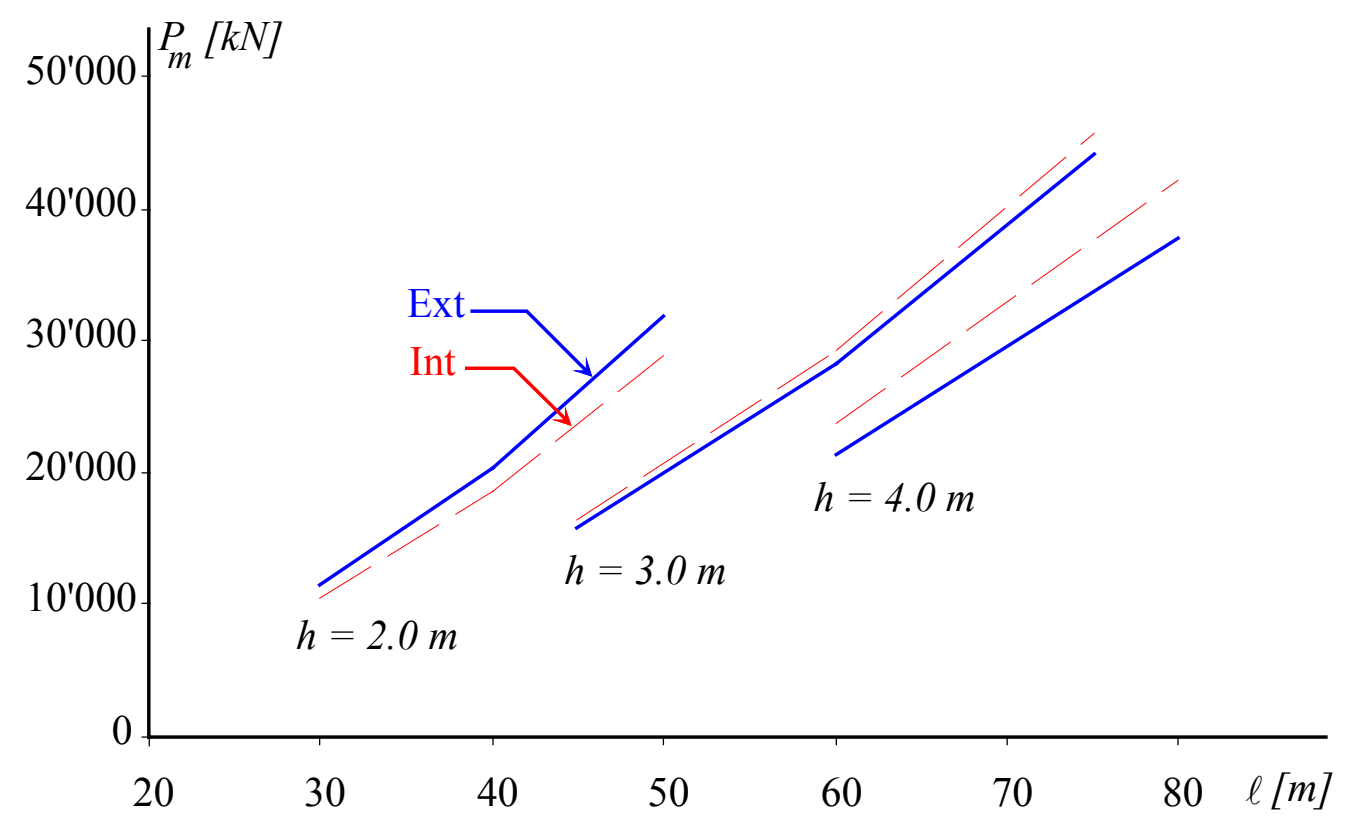

Figure 5: $\quad$ Influence of the girder depth on the required amount of prestressing for internal and external prestressing

The design of the bridge was then completed to satisfy ultimate limit state safety requirements, according to the present Swiss standards $[13,14]$. At this limit state, external tendons have a disadvantage, because they typically cannot reach their ultimate capacity. Taking into account the amount of "serviceability prestressing" determined before, and the minimal reinforcement requirements of the Swiss concrete code, it has been found that bridges with internal prestressing require no additional ULS reinforcement, while bridges with external tendons do (fig. 6). The amount of additional ULS reinforcement increases with the span of the bridge. Is decreases with the stress increase $\Delta \sigma$ at the ultimate limit state, which is induced by large deflections in the final ultimate limit state configuration of the structure. The required additional strength can be provided by mild reinforcement or by increasing the amount of prestressing. It must also be noted that this result is strongly dependent on the code provisions. The amount of minimal reinforcement prescribed in Eurocode [5,6] is significantly larger than that of the corresponding Swiss code. Hence, almost no additional ULS reinforcement would be needed in this case. 


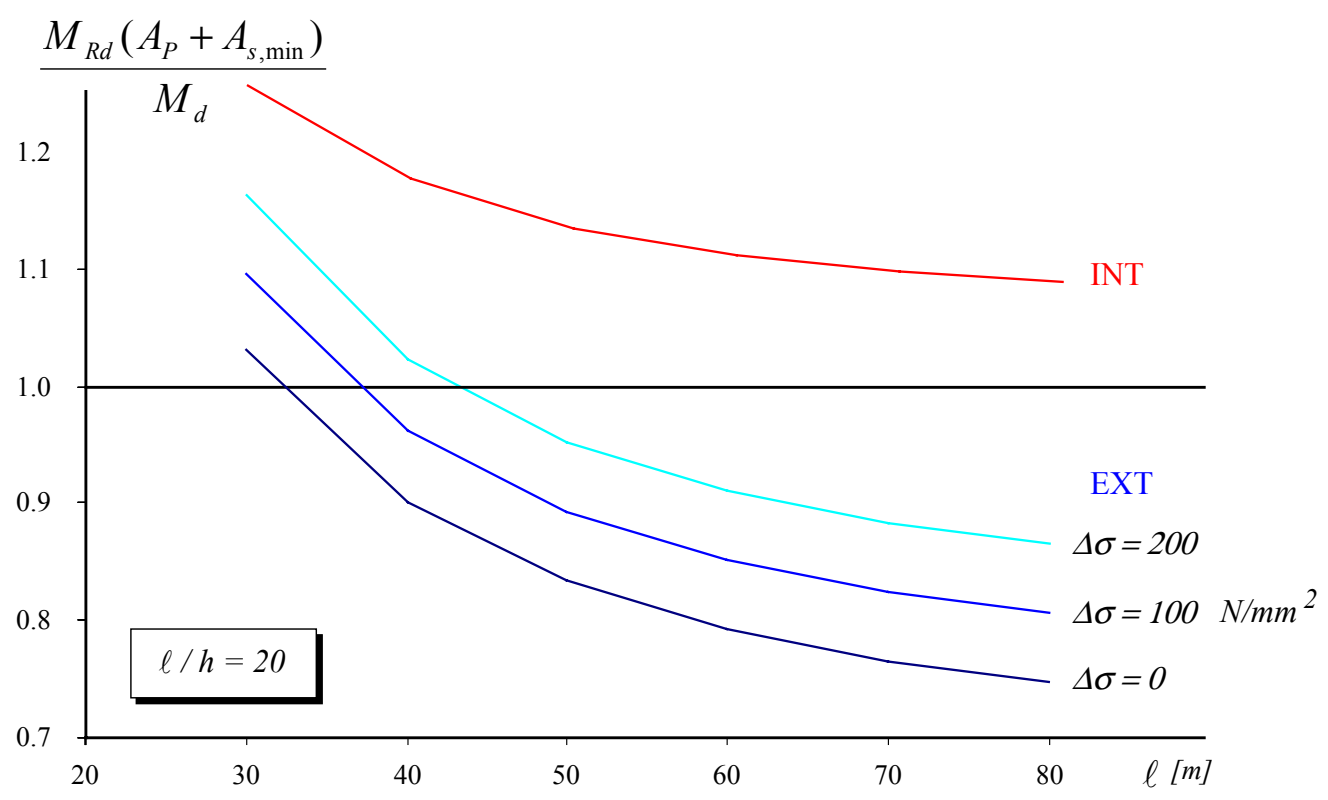

Figure 6 Reinforcement required in addition to the prestressing and the minimum reinforcement

The amount of shear reinforcement is not very different for both solutions, as figure 7 shows. Bridges with external prestressing have thinner webs, which decreases dead load but also decreases the web shear resistance. These two effects partially compensate one another, leaving a relatively small advantage to the solution with internal prestressing.

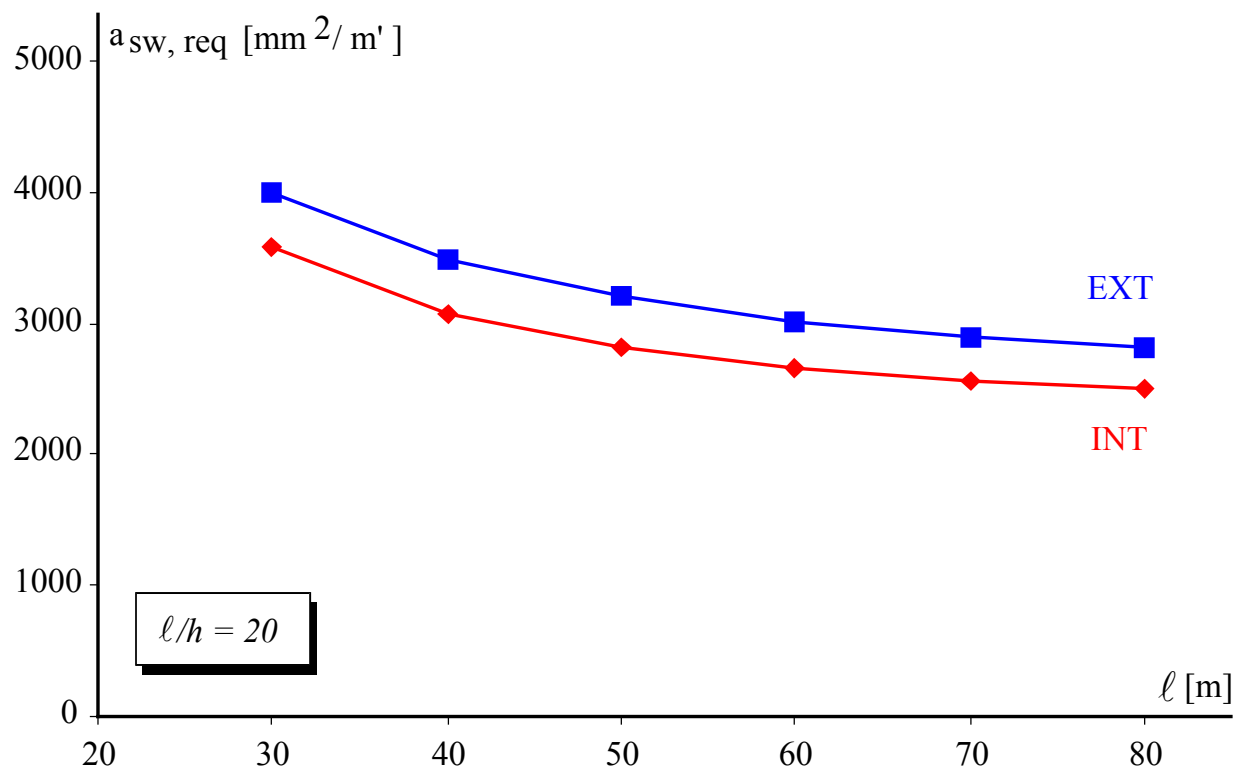

Figure $7 \quad$ Required web shear reinforcement for bridges with internal and external prestressing

\section{Conclusions}

The parallel design of a typical box girder highway bridge with internal and external tendons has shown that the differences between the two solutions are smaller than anticipated. For small spans, or more appropriately for shallow cross sections (less than about $3 \mathrm{~m}$ ), the solution with internal tendons leads to a smaller amount of reinforcement, both passive and prestressed. For deeper cross sections, the solution with external tendons requires less reinforcement. 
In spite of a disadvantage at the ultimate limit state because of the inability to fully reach the tendons load capacity, the solution with external tendons can be competitive in terms of reinforcement amount. For most practical cases, the difference between the two solutions with internal and external prestressing are small. Thus, the amount of prestressing should not be used as a criterion for the choice of either solution. Instead, the choice should be based on other criteria related to the respective advantages of the two types of prestressing.

\section{Acknowledgements}

This research project on external prestressing is funded by the Swiss Federal Highway Administration (FEDROU) This support is graciously acknowledged.

\section{References}

[1] BADOUX M., BURDET O., BENOUAICH D., Comparison of the amount of reinforcement for a box-girder bridge prestressed with Internal or external cables, fib Symposium 1999, Prague, 1999.

[2] BURDET O., BADOUX M., Long-term deflection monitoring of prestressed concrete bridges retrofitted by external post-tensioning - examples from Switzerland, IABSE Rio 1999, Rio de Janeiro, Brazil, 1999.

[3] CONTI E., FOURE B., External prestressing in structures, proceedings of the workshop on behavior of external prestressing in structures, Saint-Rémy-lès-Chevreuse, France, 1993.

[4] EIBL J., Externe Vorspannung und Segmentbauweise, Vorträge anlässlich des Workshops Externe und verbundlose Vorspannung-Segmentbrücken an der Uni Karlsruhe vom 5. Bis 7. Oktober 1998, Karlsruhe, Allemagne, allemand/anglais, 1998.

[5] EUROCODE 2, Calcul des structures en béton, partie 1: Règles générales et règles pour le bâtiment, Prénorme européenne SIA V 162.001, Zürich, 1993.

[6] EUROCODE 2, calcul des structures en béton, partie 2: Ponts en béton, Prénorme européenne SIA V 162.008, Zürich, 1996.

[7] GAUVREAU D.P., Ultimate limit state of concrete girders prestressed with unbonded tendons, ETHZ-IBK, Birkhäuser Verlag Basel, 198, Zürich, 1993.

[8] GOMEZ M., BAILEY S. F., Etude de l'effet de la normalisation européenne en Suisse, Mandat de recherche 87/94 de l'Office Fédéral des Routes, Rapport EPFL-ICOM 352, 1998.

[9] HINDI A., MACGREGOR R., KREGER M.E., BREEN J.E., Enhancing strength and ductility of post-tensioned segmental box girder bridges, ACI Structural Journal, 92, 33-44, 1995.

[10] FAVRE R., BURDET O., CHARIF H. et AL., Enseignements tirés d'essais de charge et d'observations à long terme pour l'évaluation des ponts en béton et le choix de la précontrainte, Rapport OFR $n^{\circ}$ 514, Zürich, 1995.

[11] FAVRE R. and MARKEY I., Generalization of the Load Balancing Method, 12th FIP Congress, Béton Précontraint en Suisse, pp. 32-37, Washington, USA, 1994.

[12] PICARD A., MASSICOTTE B., BASTIEN J., Relative efficiency of external prestressing, Journal of Structural Engineering, 1832-1841, 1995.

[13] SIA 160, Actions sur les structures porteuses, Société Suisse des Ingénieurs et des Architectes - Norme, Vol. 160, Zürich, 1989.

[14] SIA 162, Ouvrages en béton, Société Suisse des Ingénieurs et des Architectes - Norme, Vol. 162, Zürich, révision partielle, 1993.

[15] STANDFUSS F., ABEL M., HAVERESCH K.H., Erläuterungen zur Richtlinie für Betonbrücken mit externen Spanngliedern, Beton-und Stahlbetonbau, 93, 264-272, 1998.

[16] VIRLOGEUX M., CHAUSSIN R., JARTOUX P., Précontrainte extérieure, Annales de l'ITBTP, France, 1990. 